\title{
Mor og far i antikken
}

Gilhus IS, Seim TK, Vidén G. Farsmakt og moderskap i antikken

205 s, ill. Oslo: Scandinavian Academic Press, 2009. Pris NOK 299

ISBN 978-82-304-0041-8

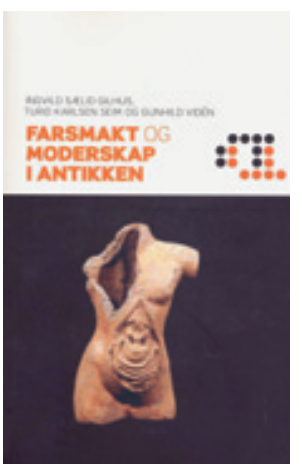

Tittelen er ikke tilfeldig - den alternative «morsmakt og faderskap» ville ha vært helt utenkelig, gitt at rammen er de fem hundre årene på hver side $a v$ vår tidsregnings begynnelse. Målet er å gi innblikk i forestillinger knyttet til unnfangelse, svangerskap, fødsel og foreldreroller i den antikke verden. I en diskusjon av forholdet mellom mor og datter brukes en av de homeriske hymner som bakteppe - og om Demeter-fortellingene sier forfatterne: «Myten sier mye om meget, sosialt så vel som psykologisk.» Det samme kan sies om denne lille utgivelsen den tar for seg mye om meget på bare 200 små sider.

Gresk (romersk) mytologi, romersk his- torie og litteratur, homeriske hymner og Hesiod, antikke avbildninger, Bibelen og apokryfe tekster fra Nag Hammadi-funnet (Johannes' hemmelige bok, Thomas-evangeliet, Filips-evangeliet osv.) tjener som utgangspunkt for fremstilling og diskusjon. Det er ingen liten munnfull, men forfatternes forskjellige faglige bakgrunn fra henholdsvis teologi (Turid Karlsen Seim), religionshistorie (Ingvild Sælid Gilhus) og klassisk filologi (Gunhild Vidén) gjør at dette brede kildetilfanget belyses fra flere sider. Tekstene og perspektivene er integrert på en måte som gjør lesingen til en fornøyelse, skjerper nysgjerrigheten og gir ideer til videre utforsking.

\section{Nye perspektiver på antikken}

Hvis ens forestilling om den antikke verden bare rommer, slik tradisjonen har vært, trojanerkrigen (Homer), perserkrigene (Herodot), peloponneserkrigen (Thukydid), Romas første kriger (Titus Livius) og den tidlige keisertid (Suetonius og Tacitus) er det på høy tid at perspektivet endres.

Kvinne-, barne- og foreldreverdenen kan også leses ut av de samme tekster, men har fått mye mindre oppmerksomhet. Det er all grunn til å være de tre forfatterne takknemlig for en så flott fremstilling

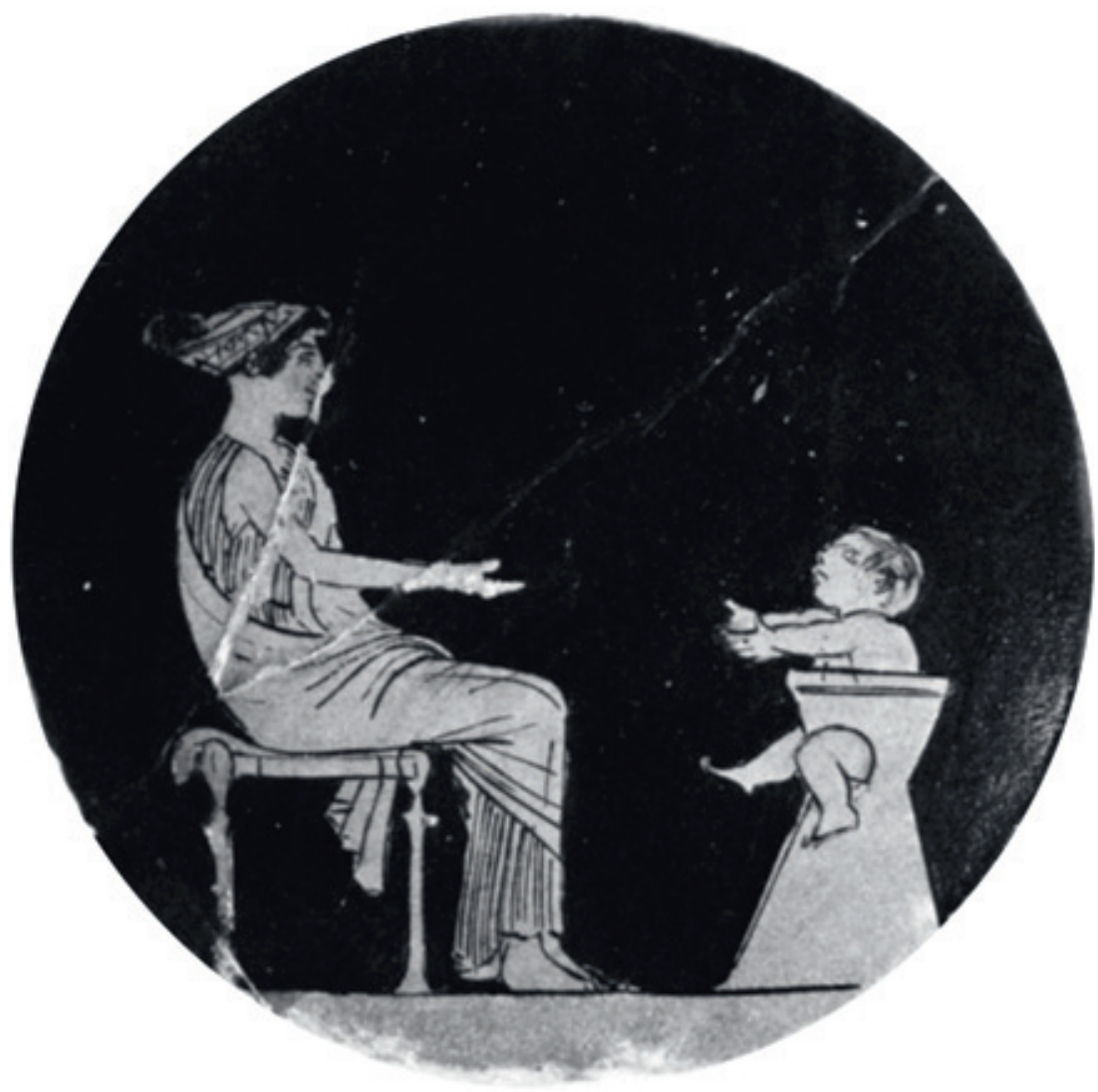

Et lite barn i barnestol strekker armene mot en kvinne (moren?), et ofte gjentatt motiv. Skålbunn, Athen ca. 475-450 f.Kr. Fra boken

som vi nå har fătt på norsk. Dette er en berikelse i vår forståelse av antikken. I engelskspråklige bøker med tilsvarende temaer fra perioden er synsfeltet ofte mye smalere

$(1,2)$.

Vi får vite mye om kvinnens sosiale plassering, om seksualitet og om et dagligliv som har hatt liten plass i de klassiske fremstillinger. Hvordan var det å være gravid og føde $\mathrm{i}$ en verden preget av magi, uten tilgang til den hjelp vi i dag regner som selvsagt. Og hvordan var det å være mor når bare tre av 12 barn levde opp? Hva betydde det for kjærligheten til det nyfødte barn våget man? Spørsmålet er påtrengende for en stor del av verdens befolkning også i 2009. Her er eksemplene hentet fra det romerske sosiale toppsjikt, Cornelia og Tiberius Gracchus. Keiser Augustus hadde selv en datter med sin første hustru. Med den berømte Livia fikk han et prematurt barn, som ikke overlevde fødselen.

\section{Ønsker for en fremtidig nyutgivelse}

Av en så god bok er det lov å ønske seg mer. Registeret kunne gjerne vært mer detaljert, selv om dette først og fremst er noe man leser fra perm til perm. I litteraturlisten ville jeg ha flere henvisninger til oversettelser av teksteksemplene, så kunne man selv lese videre ut fra tekstbrokkene. På dansk finnes f.eks. både de homeriske hymner og Hesiods Theogonien i gode utgaver.

En ny utgave burde være større. Flere illustrasjoner er mindre viktig enn en bredere fremstilling - den greske mytologien alene kunne gitt eksempler til en større utgivelse enn denne. Det samme kan sies om den siste delen, som omfatter både bibelske tekster og tekster med tilknytning til de bibelske motiver.

Hvem er Farsmakt og moderskap $i$ antikken skrevet for? Svaret må være «den allment interesserte leser», men jeg vil særlig anbefale den til kolleger som arbeider profesjonelt med hovedtemaene kjønnsroller, seksualitet, svangerskap, fødsel og forelderskap. Jeg håper den får en bred utbredelse. Den er godt skrevet, lett å lese og gir innimellom noen spennende pek, som det om ulven og Romas grunnleggelse. Hva er det med ulven? Les selv.

\section{Per E. Børdahl}

Kvinneklinikken

Haukeland universitetssykehus

\section{Litteratur}

- Dean-Jones LA. Women's bodies in classical Greek science. Oxford: Clarendon Press, 1994.

2. Demand N. Birth, death, and motherhood in classical Greece. Baltimore: Johns Hopkins University Press, 1994. 